\title{
Trends in the Annual Incidence of Carbapenem Resistant among Gram Negative Bacilli in a Large Teaching Hospital in Makah City, Saudi Arabia
}

\author{
Hani S. Faidah1, Aiman M. Momenah1, Hamdi M. El-Said1 ${ }^{*}$, Abeer A. A. Barhameen"1, \\ Sami S. Ashgar ${ }^{1}$, Ayman Johargy ${ }^{1}$, Abdelrahman Elsawy ${ }^{2,3}$, Wafaa Almalki ${ }^{4}$, \\ Samah Al Qurashi ${ }^{4}$ \\ ${ }^{1}$ Department of Medical Microbiology, Faculty of Medicine, Umm Al-Qura University, Makkah, Saudi Arabia \\ ${ }^{2}$ Al-Noor Specialist Hospital, Makah, Saudi Arabia \\ ${ }^{3}$ Department of Medical Microbiology, Faculty of Medicine, Al-Azhar University, Cairo, Egypt \\ ${ }^{4}$ Faculty of Medicine, Umm Al-Qura University, Makkah, Saudi Arabia \\ Email: *hamdimustafa1@gmail.com
}

How to cite this paper: Faidah, H.S., Momenah, A.M., El-Said, H.M., Barhameen, A.A.A., Ashgar, S.S., Johargy, A., Elsawy, A., Almalki, W. and Al Qurashi, S. (2017) Trends in the Annual Incidence of Carbapenem Resistant among Gram Negative Bacilli in a Large Teaching Hospital in Makah City, Saudi Arabia. Journal of Tuberculosis Research, 5, 229-239. https://doi.org/10.4236/jtr.2017.54024

Received: October 13, 2017

Accepted: November 5, 2017

Published: November 8, 2017

Copyright (C) 2017 by authors and Scientific Research Publishing Inc. This work is licensed under the Creative Commons Attribution International License (CC BY 4.0). http://creativecommons.org/licenses/by/4.0/ Open Access

\begin{abstract}
Objective: To detect the prevalence of carbapenem resistance among Gram negative bacilli at the Al-Noor Specialist Hospital in the western part of Saudi Arabia. Materials and Methods: This study was conducted in the Microbiology department, Al-Noor Specialist Hospital, Makah city, Saudi Arabia. The clinical samples were collected from admitted patients in the wards, Intensive Care Units (ICUs), urology unit and surgery unit, these samples included blood, urine, sputum, pus and wound. The identification and antibiotic susceptibility testing of all bacterial isolates were performed via the Vitek 2 Compact System. Results: Out of 4803 Gram negative bacterial bacilli were isolated, the prevalence rate of carbapenem resistance among these isolates was $2797 / 4803$ (58.23\%), and sensitivity rate was $2006 / 4803$ (41.77\%) of the total isolates. The rate of resistance to carbapenem was among Acinetobacter baumannii 1710 (99.13\%), followed by Pseudomonas aeruginosa 575 (62.4\%), Klebsiella pneumoniae 459 (38\%) and Escherichia coli 56 (5.59\%). The trend of carbapenem resistance among Gram negative bacterial isolates from 2013-2015 was 53.99\%, 59.88\% and 61.43\% respectively. Conclusion: A. baumannii recorded, the highest rate of carbapenem resistance through three year, $98.19 \%, 99.48 \%$ and $99.81 \%$ respectively and the lowest rate of resistance recorded with E. coli, $4.63 \%, 5.79 \%$ and $6.31 \%$ respectively.
\end{abstract}




\section{Keywords}

Carbapenem Resistance, Acinetobacter baumannii, Makah, Pathogens

\section{Introduction}

Carbapenems antibiotics, which include imipenem, meropenem, doripenem and ertapenem, have very significant role for treating severe bacterial infections. They quickly enter to the cell wall through the proteins found in the outer membrane (PBPs) in Gram negative bacteria [1] [2]. This group of antibiotics are the most common used in treatment of infections that life threatening, as well as they used as last line for treating and defense against multidrug resistant strains such as Acinetobacter baumanniim, Pseudomonas aeruginosa, Klebsiella pneumoniae and Escherichia coli [3] [4]. These bacteria species are the most common pathogens of human and considered as main cause of hospital acquired infections. Nosocomial infections have a significant role in transmission of resistant strains [5]. In recent years, there is a quick decline in the effectiveness of carbapenems antibiotics in treatment of serious bacterial infections, which considered a threat to public health [6] [7] [8]. Carbapenims resistance may occur, due to the secretion of enzymes and genes which are responsible from reduced susceptibility and resistance to carbapenems such as oxacillinase-48 (OXA-48), Klebsiella pneumonia carbapenemase (KPC) and New Delhi metallo-betalactamase-1 (NDM-1). Horizontal gene transfer mechanisms like transformation, transduction and conjugation can spread resistance genes, as well and these enzymes have the ability to break down carbepenems and prevent them from reaching PBPs, makes them ineffective [9] [10] [11]. World Health Organization (WHO) reported that infections caused by Gram negative bacterial bacilli threaten the lives of many patients in intensive care units (ICUs) around the world due to its resistance to carbapenems, and the rate of mortality among those patients ranges from $25 \%$ to $75 \%$ [12]. The studies have indicated that carbapenems resistance among Gram negative bacteria has become a global issue [13]. Recent studies showed that Saudi Arabia is considered among the countries that reported high rates of antimicrobial resistance [14] [15]. Thus, this study aimed to detect the prevalence of carbapenem resistance among Gram negative bacteria at the Al-Noor Specialist Hospital in the western part of Saudi Arabia, and monitoring to carbapenem resistance among these types of bacteria in order to devise strategies to counter threats from these extremely dangerous bacteria.

\section{Materials and Methods}

Specimens collection and processing, this study was conducted at the microbiology department in the Al-Noor Specialist Hospital, Makah city, Saudi Arabia, during three years from November 2012 to December 2015. Clinical specimens were collected from patients in three wards in the hospital, Intensive Care Unit 
(ICU), Urology and Surgery units, these samples included blood, urine, sputum, pus and wound swabs.

Bacterial isolation and identification, all clinical specimens were cultured on blood agar, MacConkey's agar and incubated under aerobic conditions for 24 hours at $37^{\circ} \mathrm{C}$. The identification of isolated organisms was carried out by colonial morphology, Gram stained films and the species identification performed vie the VITEK 2 Compact System (Bio-Merieux).

Antibiotic susceptibility testing, for isolated organisms such as Acinetobacter baumannii, Pseudomonas aeruginosa, Klebsiella pneumonia and Escherichia coli were carried out by VITEK 2 Compact System (Bio-Merieux). The isolates which were showed elevated MIC to meropenem and imipenem; as well as resistance to cefiriaxone, cefotaxime and ceftazidime (Third generation cephalosporin's) were considered to be carbapenem resistant. The resistance breakpoints used for detecting carbapenem resistance was $\geq 4 \mu \mathrm{g} / \mathrm{ml}$ for imipenem and meropenem. The resistance breakpoints used for ceftazidime and cefotaxime were $\geq 32 \mu \mathrm{g} / \mathrm{ml}$ where ceftriaxone was $\geq 64 \mu \mathrm{g} / \mathrm{ml}$, according to Clinical and Laboratory Standards Institute (CLSI) guidelines.

\section{Results}

Out of 4803 Gram negative bacilli isolated from different clinical specimens in this study, The prevalence rate of carbapenem resistance among Gram-negative isolates were $2797 / 4803$ (58.23\%), and sensitivity rate were 2006/4803 (41.77\%) of the total isolates, 1001 (20.84\%) was E. coli, 1158 (24.10\%) K. pneumonia, 922 (19.19\%) P. aeruginosa and 1722 (35.85\%) A. baumannii. The maximum number of isolated bacteria was from sputum 1773 (36.91), followed by wound swabs 1513 (31.50\%), blood 913 (19\%), urine 566 (11.78\%) and Pus 38 (0.79\%). The high rate of resistance between both meropenem and imipenem was $A$. baumarmii 1710/1722 (99.13\%), followed by $p$. aeruginosa 575/922 (62.4\%), $K$. pneumoniae 459/1158 (38\%) and E. coli 56/1001 (5.59\%) (Table 1).

Majority of resistant strains among different locations of the hospital, were isolated from ICU, 3573/4803 (74.39\%), followed by $1044 / 4803$ (21.73\%) from surgery unit and 186/4803 (3.87) from urology unit.

$A$ baumannii was the most common microorganism isolated from ICU patients (Table 2).

The trend of carbapenem resistance among Gram-negative bacterial isolates from November 2012 to December 2015 was 933/1728 (53.99\%), 972/1623 (59.88\%) and 892/1452 (61.43\%) respectively. In 2013, 1728 isolates were examined for Carbapenem resistance, among of these isolates, 933 (53.99\%) strains were resistant to carbapenem included A. baumannii 98.19\% (597/608), P. aeruginosa 53.63\% (192/358), K. pneumonia 30.69\% (128/417) and E. coil 4.63\% (16/345). In 2014, 1623 isolates were examined for Carbapenem resistance, among of these isolates, $972(59.88 \%)$ strains were resistant to carbapenems, included $A$. baumannii 99.48\% (581/584), P. aeruginosa 58.30\% (207/355), K. pneumonia 
Table 1. Rate of carbapenems resistance among Gram negative bacterial isolates in clinical samples.

\begin{tabular}{|c|c|c|c|c|c|c|c|c|c|c|c|c|}
\hline \multirow{3}{*}{ 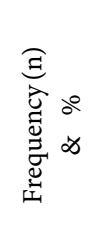 } & \multicolumn{12}{|c|}{ Gram Negative Bacterial Isolates } \\
\hline & \multicolumn{3}{|c|}{ E. coli } & \multicolumn{3}{|c|}{ K. pneumonia } & \multicolumn{3}{|c|}{$P$. aeruginosa } & \multicolumn{3}{|c|}{ A. baumannii } \\
\hline & $\begin{array}{l}\text { Carbapenem } \\
\text { sensitive } \\
\text { n (\%) }\end{array}$ & $\begin{array}{c}\text { Carbapenem } \\
\text { resistant } \\
\mathrm{n}(\%)\end{array}$ & $\begin{array}{c}\text { Total } \\
\mathrm{n}\end{array}$ & $\begin{array}{c}\text { Carbapenem } \\
\text { sensitive } \\
\mathrm{n}(\%)\end{array}$ & $\begin{array}{l}\text { Carbapenem } \\
\text { resistant } \\
\mathrm{n}(\%)\end{array}$ & $\begin{array}{c}\text { Total } \\
\mathrm{n}\end{array}$ & $\begin{array}{c}\text { Carbapenem } \\
\text { sensitive } \\
\mathrm{n}(\%)\end{array}$ & $\begin{array}{c}\text { Carbapenem } \\
\text { resistant } \\
\mathrm{n}(\%)\end{array}$ & $\begin{array}{c}\text { Total } \\
\mathrm{n}\end{array}$ & $\begin{array}{c}\text { Carbapenem } \\
\text { sensitive } \\
\mathrm{n}(\%)\end{array}$ & $\begin{array}{c}\text { Carbapenem } \\
\text { resistant } \\
\mathrm{n}(\%)\end{array}$ & $\begin{array}{c}\text { Total } \\
\mathrm{n}\end{array}$ \\
\hline $\begin{array}{c}\text { URINE } \\
566 \\
(11.78 \%)\end{array}$ & $\begin{array}{c}309 \\
(97.2 \%)\end{array}$ & $\begin{array}{c}9 \\
(3.8 \%)\end{array}$ & 318 & $\begin{array}{c}112 \\
(72 \%)\end{array}$ & $\begin{array}{c}44 \\
(28 \%)\end{array}$ & 156 & $\begin{array}{c}24 \\
(50 \%)\end{array}$ & $\begin{array}{c}24 \\
(51 \%)\end{array}$ & 48 & $\begin{array}{c}0 \\
(0 \%)\end{array}$ & $\begin{array}{c}44 \\
(100 \%)\end{array}$ & 44 \\
\hline $\begin{array}{l}\text { Sputum } \\
1773 \\
(36.91)\end{array}$ & $\begin{array}{c}91 \\
(82 \%)\end{array}$ & $\begin{array}{c}20 \\
(12 \%)\end{array}$ & 111 & $\begin{array}{c}126 \\
(43 \%)\end{array}$ & $\begin{array}{c}166 \\
(47 \%)\end{array}$ & 292 & $\begin{array}{c}122 \\
(31 \%)\end{array}$ & $\begin{array}{c}273 \\
(69 \%)\end{array}$ & 395 & $\begin{array}{c}4 \\
(0.4 \%)\end{array}$ & $\begin{array}{c}971 \\
(99.6 \%)\end{array}$ & 975 \\
\hline $\begin{array}{c}\text { Blood } \\
913 \\
(19 \%)\end{array}$ & $\begin{array}{c}258 \\
(95 \%)\end{array}$ & $\begin{array}{c}14 \\
(5 \%)\end{array}$ & 272 & $\begin{array}{c}234 \\
(64 \%)\end{array}$ & $\begin{array}{c}132 \\
(36 \%)\end{array}$ & 366 & $\begin{array}{c}25 \\
(54 \%)\end{array}$ & $\begin{array}{c}24 \\
(46 \%)\end{array}$ & 46 & $\begin{array}{c}4 \\
(1.7 \%)\end{array}$ & $\begin{array}{c}225 \\
(98.3 \%)\end{array}$ & 229 \\
\hline $\begin{array}{c}\text { Pus } \\
38 \\
(0.79 \%)\end{array}$ & $\begin{array}{c}19 \\
(93 \%)\end{array}$ & $\begin{array}{c}2 \\
(7 \%)\end{array}$ & 21 & $\begin{array}{c}8 \\
(64 \%)\end{array}$ & $\begin{array}{c}4 \\
(36 \%)\end{array}$ & 12 & $\begin{array}{c}0 \\
(0 \%)\end{array}$ & $\begin{array}{c}3 \\
(100 \%)\end{array}$ & 3 & $\begin{array}{c}0 \\
(0 \%)\end{array}$ & $\begin{array}{c}2 \\
(100 \%)\end{array}$ & 2 \\
\hline $\begin{array}{c}\text { Wound } \\
1513 \\
(31.50 \%)\end{array}$ & $\begin{array}{c}268 \\
(96 \%)\end{array}$ & $\begin{array}{c}11 \\
(4 \%)\end{array}$ & 279 & $\begin{array}{c}219 \\
(66 \%)\end{array}$ & $\begin{array}{c}113 \\
(34 \%)\end{array}$ & 332 & $\begin{array}{c}232 \\
(54 \%)\end{array}$ & $\begin{array}{c}198 \\
(46 \%)\end{array}$ & 430 & $\begin{array}{c}7 \\
(1.5 \%)\end{array}$ & $\begin{array}{c}465 \\
(98.5 \%)\end{array}$ & 472 \\
\hline $\begin{array}{l}\text { Total } \\
4803\end{array}$ & $\begin{array}{c}945 \\
(92.6 \%)\end{array}$ & $\begin{array}{c}56 \\
(5.59 \%)\end{array}$ & 1001 & $\begin{array}{c}699 \\
(62 \%)\end{array}$ & $\begin{array}{c}459 \\
(38 \%)\end{array}$ & 1158 & $\begin{array}{c}347 \\
(37.6 \%)\end{array}$ & $\begin{array}{c}575 \\
(62.4 \%)\end{array}$ & 922 & $\begin{array}{c}12 \\
(0.7 \%)\end{array}$ & $\begin{array}{c}1710 \\
(99.3 \%)\end{array}$ & 1722 \\
\hline
\end{tabular}

Table 2. Distribution of carbapenems resistant strains among different locations.

\begin{tabular}{|c|c|c|c|c|c|}
\hline \multirow{2}{*}{ 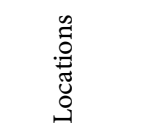 } & \multicolumn{5}{|c|}{ Carbapenems resistant strains \% } \\
\hline & E. coli n (\%) & $\begin{array}{c}K \cdot \text { pneumonia } \\
\mathrm{n}(\%)\end{array}$ & $\begin{array}{c}P \text {. aeruginosa } \\
\mathrm{n}(\%)\end{array}$ & $\begin{array}{c}\text { A. baumannii } \\
\mathrm{n}(\%)\end{array}$ & Total n (\%) \\
\hline \multirow{2}{*}{ ICU } & 549 & 888 & 628 & 1508 & 3573 \\
\hline & $(15.36)$ & $(24.85)$ & $(17.57)$ & $(42.20)$ & $(74.40 \%)$ \\
\hline \multirow{2}{*}{ Surgery } & 361 & 225 & 273 & 185 & 1044 \\
\hline & $(34.57)$ & $(21.55)$ & $(26.14)$ & $(17.72)$ & $(21.73 \%)$ \\
\hline \multirow{2}{*}{ UROLOGY } & 91 & 45 & 21 & 29 & 186 \\
\hline & $(48.92)$ & $(24.19)$ & $(11.29)$ & $(15.59)$ & $(3.87 \%)$ \\
\hline \multirow{2}{*}{ Total } & 1001 & 1158 & 922 & 1722 & 4803 \\
\hline & (20.85) & $(24.10)$ & (19.20) & (35.85) & (100\%) \\
\hline
\end{tabular}

41.17\% (168/408) and E. coli 5.79\% (16/276). 1n 2015, 1452 isolates were examined for Carbapenem resistance as well, among these isolates, 892 (61.43\%) strains were resistant to carbapenems, included A. baumannii 99.81\% (529/530), 
P. aeruginosa $84.21 \%(176 / 209)$, $K$. pneumonia $54.27 \%(163 / 333)$ and $E$. coli $6.31 \%(24 / 380)$. Organisms showed increasing trend of carbapenem resistance among Gram-negative bacterial isolates from 2013-2015, generally the highest rate of carbapenem resistance during the three years was $A$. baumannii which recorded $98.19 \%, 99.48 \%$ and $99.81 \%$ respectively and the lowest rate of carbapenem resistance was $E$. coli which recorded $4.63 \%, 5.79 \%$ and $6.31 \%$ respectively (Table 3 ).

\section{Discussion}

In recent years, carbapenem resistance in Gram negative bacteria has been reported worldwide with increasing frequency. Carbapenemase production is a mechanism of carbapenem resistance. Carbapenem hydrolyzing enzymes are most commonly seen in $P$. aeruginosa and $A$. baumannii, however in the recent years, there are an increasing incidence of these enzymes in $K$. pneumoniae and E. coli. In the current study, 2797 (58.23\%) of the total 4803 Gram negative bacterial isolates were resistant to carbapnems, $A$. baumannii was the most common isolates among this group followed by $P$. aeruginosa, $K$. pneumonia and $E$. coli respectively. This study shown a high rate of carbapenem resistant among Gram negative bacterial isolates at Al-Noor Specialist Hospital compared to previous studies from Saudi Arabia. Recent studies from Egypt showed that, carbapenem resistance among $A$. baumannii strains recorded (74\%) [16]. Some studies from Jordan reported a high rate of resistance to meropenem and imipenem; $(70.1 \%$ and $71.6 \%$ respectively) among $A$. baumannii in clinical isolates [17]. Where $A$. baumannii, $P$. aeruginosa were recorded resistance to carbapenem in this study 99.81\%, 84.21\% respectively. Recent study in Saudi Arabia showed that an increase in imipenem resistance among $P$. aeruginosa isolates increased from $20 \%$ in 2004 to $38.57 \%$ in 2011, another study in 2009 and 2010 reported the

Table 3. Organisms showing trend of carbapenem resistance among Gram-negative bacterial isolates from 2013-2015.

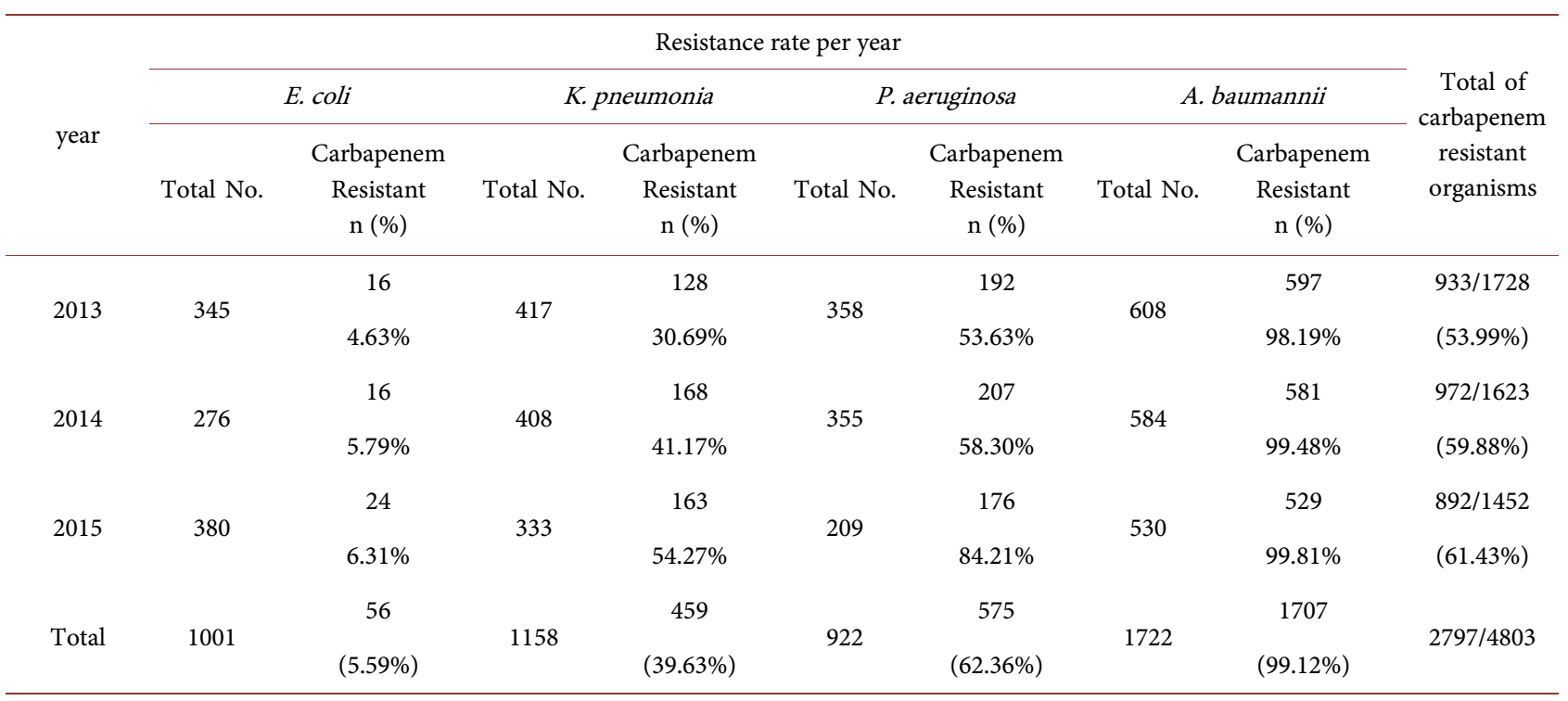


high rate of carbapnem resistance among $P$. aeruginosa isolates ranged from $36 \%$ to $53 \%$ to meropenem and imipenem respectively [18] [19]. Several studies around the world shown increasing trend of carbapenem resistant among $P$. aerugenosa ranged from ( $4 \%-60 \%)$, thus, $P$. aerugenosa and $A$. baumanii became constituted risks according to many reports [20] [21]. This study shown that, carbapnem resistance among $K$. pneumonia isolates were $30.69 \%, 41.17 \%$ and $54.27 \%$ respectively, followed by $E$. coli which was $4.63 \%, 5.79 \%$ and $6.31 \%$ respectively during the three years. The degree of carbapnems resistance in the current study was higher than the results in a study conducted in Egypt in 2013 concluded that carbapnem resistance enterobacteriaceae were, 53\% to meropenem and 36\% to imipenem [22]. In Saudi Arabia, a study reported high rate of carbapenem resistance $48 \%$ among $K$. pneumonia isolates, as well as another studies from Gulf countries confirmed emergence of NDM-1 and OXA-48 among $K$. pneumonia strains in Saudi Arabia, Kuwait, Oman and United Arab Emirates [23] [24] [25].

\section{Conclusion}

The current study reported increasing to carbapenem resistance among Gram negative isolates. The highest rate of carbapenem resistance in this study was observed among $A$. baumannii and $P$. aerugenosa respectively. A. baumannii was the most common microorganism isolated from ICU patients. The high rates of carbapenem resistance among Gram negative isolates are worrisome and require steric application of surveillance systems and infection control as well as early detection and the accurate selection of antibiotics in clinical practice against these microorganisms. However, this study highlighted the current situation of carbepenam resistance amongst Gram negative bacterial isolates in this region.

\section{Acknowledgements}

We would like to thank the laboratory department, Al-Noor Specialist Hospital, Makah, Saudi Arabia for their support to carry out the study. We would also like to thank the Microbiology staff, Al-Noor Specialist Hospital for their cooperation during the performing this study.

\section{Conflict of Interest}

The authors declare no conflict of interest.

\section{References}

[1] Paterson, D.L. and Bonomo, R.A. (2005) Extended-Spectrum $\beta$-Lactamases: A Clinical Update. Clinical Microbiology Reviews, 18, 657-686. https://doi.org/10.1128/CMR.18.4.657-686.2005

[2] Gaynes, R.P. and Culver, D.H. (1992) Resistance to Imipenem among Selected Gram Negative Bacilli in the United States. Infection Control \& Hospital Epidemiology, 13, 10-14. https://doi.org/10.2307/30146962 
[3] Lee, K., Lim, Y.S., Yong, D., et al. (2003) Evaluation of the Hodge Test and the Imipenem-EDTA Double-Disk Synergy Test for Differentiating Metallo- $\beta$-Lactamase Producing Isolates of Pseudomonas spp. and Acinetobacter spp. Journal of Clinical Microbiology, 41, 4623-4629. https://doi.org/10.1128/JCM.41.10.4623-4629.2003

[4] Papp Wallace, K.M., Endimiani, A., Taracila, M.A., et al. (2011) Carbapenems: Past, Present, and Future. Antimicrobial Agents and Chemotherapy, 55, 4943-4960. https://doi.org/10.1128/AAC.00296-11

[5] Nordmann, P., Naas, T. and Poirel, L. (2011) Global Spread of CarbapenemaseProducing Enterobacteriaceae. Emerging Infectious Diseases, 17, 1791-1798. https://doi.org/10.3201/eid1710.110655

[6] Tiwari, P., Rohit, M. and Pharm, M. (2013) Assessment of Costs Associated with Hospital-Acquired Infections in a Private Tertiary Care Hospital in India. Value in Health Regional Issue, 2, 87-91. https://doi.org/10.1016/j.vhri.2013.03.002

[7] Agarwal, S., Kakati, B., Khanduri, S., et al. (2017) Emergence of Carbapenem Resistant Non-Fermenting Gram-Negative Bacilli Isolated in an ICU of a Tertiary Care Hospital. Journal of Clinical and Diagnostic Research, 11, DC04-DC07. https://doi.org/10.7860/JCDR/2017/24023.9317

[8] Falagas, M.E., Lourida, P., Poulikakos, P., et al. (2014) Antibiotic Treatment of Infections Due to Carbapenem-Resistant Enterobacteriaceae: Systematic Evaluation of the Available Evidence. Antimicrobial Agents and Chemotherapy, 58, 654-663. https://doi.org/10.1128/AAC.01222-13

[9] Patel, J.B., Rasheed, J.K. and Kitchel, B. (2009) Carbapenemases in Enterobacteriaceae: Activity, Epidemiology, and Laboratory Detection. Clinical Microbiology Newsletter, 31, 55-62. https://doi.org/10.1016/j.clinmicnews.2009.03.005

[10] Martin, E.T., Tansek, R., Collins, V., et al. (2013) The Carbapenem Resistant Enterobacteriaceae Score: A Bedside Score to Rule Out Infection with Carbapenem Resistant Enterobacteriaceae among Hospitalized Patients. American Journal of Infection Control, 41, 180-182. https://doi.org/10.1016/j.ajic.2012.02.036

[11] Nordmann, P., Dortet, L. and Poirel, L. (2012) Carbapenem Resistance in Enterobacteriaceae: Here Is the Storm! Trends in Molecular Medicine, 18, 263-272. https://doi.org/10.1016/j.molmed.2012.03.003

[12] Organization, W.H. (2014) Antimicrobial Resistance: Global Report on Surveillance. World Health Organization, Geneva, 257.

[13] Karaiskos, I. and Giamarellou, H. (2014) Multidrug-Resistant and Extensively Drug-Resistant Gram-Negative Pathogens: Current and Emerging Therapeutic Approaches. Expert Opinion on Pharmacotherapy, 15, 1351-1370. https://doi.org/10.1517/14656566.2014.914172

[14] Alsultan, A.A., Evans, B.A., Elsayed, E.A., et al. (2013) High Frequency of Carbapenem Resistant Acinetobacter baumannii in Patients with Diabetes Mellitus in Saudi Arabia. Journal of Medical Microbiology, 62, 885-888. https://doi.org/10.1099/jmm.0.057216-0

[15] Ahmed, N.H., Hussain, T. and Biswal, I. (2015) Antimicrobial Resistance of Bacterial Isolates from Respiratory Secretions of Ventilated Patients in a Multi-Speciality Hospital. Avicenna Journal of Medicine, 5, 74-78.

https://doi.org/10.4103/2231-0770.160233

[16] Fouad, M., Attia, A.S., Tawakkol, W.M. and Hashem, A.M. (2013) Emergence of Carbapenem-Resistant Acinetobacter baumannii Harboring the OXA-23 Carbapenemase in Intensive Care Units of Egyptian Hospitals. International Journal of Infectious Diseases, 17, 1252-1254. https://doi.org/10.1016/j.ijid.2013.07.012 
[17] Dhabaan, G.N., Hamimah, H. and Shorman, M.A. (2011) Emergence of Extensive Drug-Resistant Acinetobacter baumannii in North of Jordan. African Journal of Microbiology Research, 5, 1070-1075.

[18] Zafer, M.M., Al-Agamy, M.H., E1-Mahallawy, H.A., Amin, M.A.M.Z. and Ashour, M.S.E. (2014) Antimicrobial Resistance Pattern and Their Beta-Lactamase Encoding Genes among Pseudomonas aeruginosa Strains Isolated from Cancer Patients. BioMed Research International, 2014, Article ID: 101635, 8 p.

[19] Al-Agmy, M.H., Shibl, A.M., Tawfik, A.F., Elkhizzi, N.A. and Livermore, D.M. (2012) Extended Spectrum and Metallo Beta Lactames among Ceftazidime Resistant Pseudomonas aeroginosa in Riyadh, Saudia Arabia. Journal of Chemotherapy, 24, 97-100. https://doi.org/10.1179/1120009X12Z.00000000015

[20] Bonomo, R.A. and Szabo, D. (2006) Mechanisms of Multidrug Resistance in Acinetobacter Species and Pseudomonas aeruginosa. Clinical Infectious Diseases, 43, S49-S56. https://doi.org/10.1086/504477

[21] Dijkshoorn, L., Nemec, A. and Seifert, H. (2007) An Increasing Threat in Hospitals: Multidrug-Resistant Acinetobacter baurnannii. Nature Reviews Microbiology, 5, 939-951. https://doi.org/10.1038/nrmicro1789

[22] Metwally, L., Gomaa, N., Attallah, M. and Kamel, N. (2013) High Prevalence of Klebsiella pneumoniae Carbapenemase-Mediated Resistance in K. pneumoniae Isolates from Egypt. Eastern Mediterranean Health Journal, 19, 947-52.

[23] Shibl, A., Al-Agamy, M., Memish, Z., Senok, A., Khader, S.A. and Assiri, A. (2013) The Emergence of OXA-48- and NDM-1-Positive Klebsiella pneumoniae in Riyadh, Saudi Arabia. International Journal of Infectious Diseases, 17, e1130-3. https://doi.org/10.1016/j.ijid.2013.06.016

[24] Dortet, L., Poirel, L., Al Yaqoubi, F. and Nordmann, P. (2012) NDM-1, OXA-48 and OXA-181 Carbapenemase-Producing Enterobacteriaceae in Sultanate of Oman. Clinical Microbiology and Infection, 18, E144-E148. https://doi.org/10.1111/j.1469-0691.2012.03796.x

[25] Poirel, L., Al Maskari, Z., Al Rashdi, F., Bernabeu, S. and Nordmann, P. (2010) NDM1-Producing Klebsiella pneumoniae Isolated in the Sultanate of Oman. Journal of Antimicrobial Chemotherapy, 66, 304-306. https://doi.org/10.1093/jac/dkq428 